\title{
Implementasi Supervisi Akademik Dalam Meningkatkan Kualitas Pembelajaran di SMA dan SMK Se-Kecamatan Abung Semuli Lampung Indonesia
}

\section{Nining Surya Ningsih, M. Ihsan Dacholfany, Sudirman Aminin}

Mahasiswa Magister Administrasi Pendidikan UM Metro

Dosen Magister Administrasi Pendidikan UM Metro

mihsandacholfany@yahoo.com

\begin{tabular}{ll}
\hline & Abstract \\
\hline Article History & Motivated by the problems of the quality of \\
Received :11-09-2020 & learning. To improve the quality of \\
Revised :18-09-2020 & teaching carried out by teachers, through \\
Accepted:25-09-2020 & educational supervision. The research was \\
Keywords: & conducted in SMA and SMK in Abung \\
Academic & Semuli Subdistrict, Lampung which aims to \\
Supervision, & describe the Principal's knowledge \\
In Improving & regarding the role of supervisor and to \\
The Quality Of & know the Implementation of Academic \\
Learning. & Supervision in Improving the Quality of \\
& Teacher Learning. Research using a \\
& qualitative research approach with \\
& phenomenological theory. Conclusions: \\
& Principals of SMA and SMK in Abung \\
& Semuli District, Lampung have good \\
& knowledge of academic supervision as \\
& evidenced by the supervision of these \\
& schools. Implementation of Academic \\
& Supervision in Improving the Quality of \\
& Learning Indonesian language teachers \\
& using individual techniques in the form of \\
& class visits begins with making a \\
& supervision program containing planning, \\
preparation, implementation, evaluation.
\end{tabular}

\section{Pendahuluan}

Permasalahan kualitas pembelajaran merupakan faktor yang sangat penting dalam pendidikan, kualitas pembelajaran sangat dipengaruhi oleh kualitas guru. Untuk meningkatkan kualitas 
mengajar yang dilakukan oleh guru, dalam penyelenggaraan sistem pendidikan dapat dibantu pencapaian tujuan pembelajaran, melalui supervisi pendidikan. Supervisi akademik adalah serangkaian kegiatan untuk membantu guru untuk mengesplorasi kemampuan yang dimiliki dalam sebuah proses pembelajaran yang akan berakibat meningkatnya kualitas pembelajaran disekolah tersebut. Untuk meningkatkan kualitas pembelajaran sangat dibutuhkan guru-guru yang mampu mengeksploitasi kurikulum menjadi unit pelajaran yang mampu diterapkan setiap kali berada didalam ruang kelas. Kelas sebagai ruang sentral interaksi guru dan siswa haruslah menyenangkan. Sebagai seorang guru tidak butuh kurikulum yang membunuh kreativitas siswa. Guru harus menjadi sosok yang tidak dominan di dalam kelas. Guru bukan orang yang tahu segalanya. Guru juga bukanlah pendidik yang berbasis kunci jawaban, melainkan guru adalah penuntun siswa agar menemukan bidang pelajaran yang paling disukainya.

Kualitas atau mutu pembelajaran ada di tangan guru namun tidak bisa dibangun hanya dengan diskusi tentang teori-teori untuk memajukan pendidikan. Peningkatan mutu pendidikan bukanlah upaya sederhana, melainkan suatu kegiatan dinamis dan penuh tantangan. Pendidikan selalu berubah seiring dengan perubahan jaman, oleh karena itu pendidikan senantiasa memerlukan upaya perbaikan dan peningkatan mutu sejalan dengan semakin tingginya kebutuhan dan tuntutan kehidupan masyarakat (Yunia, 2018:252). Banyak perdebatan tentang kurikulum yang efektif. Namun, terlalu sedikit tindakan untuk membenahi kualitas pembelajaran dan kompetensi guru dalam mendidik. Guru akan sulit menerima perubahan jika kompetensinya rendah. Pendidikan akan semakin berat ke depannya apabila kualitas pembelajarannya masih rendah, oleh karena itu, kompetensi harus ditingkatkan untuk kemajuan kualitas pendidikan Indonesia saat ini dan ke depannya, dalam hal ini guru sebagai ujung tombak dalam penyelenggaraan sistem pendidikan dapat dibantu pertumbuhan dan perkembangan profesinya bagi pencapaian tujuan pembelajaran melalui supervisi pendidikan

SMA dan SMK se-Kecamatan Abung Semuli, Lampung terdiri dari 3 sekolah yaitu SMA Negeri 1 Abung Semuli, SMKS Muhammadiyah Abung Semuli, dan SMKS Bhakti Angkasa 3 Abung Semuli, Lampung dengan total guru keseluruhan 93 guru dan 9 guru 
Bahasa Indonesia. Sekolah-sekolah tersebut memiliki lokasi yang berdekatan, karena lokasinya yang berdekatan maka sekolah-sekolah tersebut cukup kompetitif dalam meningkatkan kualitas pendidikan disekolah mereka sehingga diminati oleh siswa-siswi dari dalam dan luar wilayah Kecamatan Abung Semuli.

Berdasarkan survei penelitian yang dilaksanakan pada tanggal 3 September 2019 sampai dengan 4 Juni 2020 di SMA dan SMK seKecamatan Abung Semuli, Lampung mengenai supervisi akademik, masih ditemukan beberapa masalah, masih minimnya pengetahuan kepala sekolah tentang supervisi akademik, belum maksimalnya pelaksanaan supervisi akademik, sehingga pembelajaran masih belum berjalan sebagaimana yang diharapkan, masih didapati guru yang datang terlambat, tidak menggunakan perangkat pembelajaran ketika mengajar, hanya memberikan catatan, dan meninggalkan kelas setelah memberikan tugas. Guru terkesan jarang menjelaskan materi pembelajaran, media yang digunakan belum berfariatif, dan semua pembelajaran masih berpusat kepada guru, siswa belum diberikan kesempatan mengeksploitasi sebuah materi pembelajaran, maka penulis akan meneliti tentang Implementasi Supervisi Akademik dalam Meningkatkan Kualitas Pembelajaran di SMA dan SMK seKecamatan Abung Semuli Lampung, Indonesia.

\section{Metode Penelitian}

\section{Pendekatan dan Jenis Penelitian}

Penelitian ini menggunakan pendekatan penelitian kualitatif. Penelitian kualitatif merupakan sebuah prosedur penelitian yang menghasilkan data deskritif berbentuk tulisan tentang orang atau kata-kata orang dan perilakunya yang nampak atau kelihatan. Metode kualitatif sering disebut penelitian naturalistik karena penelitiannya dilakukan pada kondisi yang alami (natural setting). Pendekatan kualitatif memandang realita sosial sebagai sesuatu yang utuh/holistik, kompleks, dinamis, penuh makna dan hubungan yang bersifat interaktif (reciprocal).

Dalam penelitian ini diperlukan pengamatan yang mendalam dan menyeluruh, data yang diungkap bukan berupa angka-angka melainkan berupa kata-kata dan dokumen. Penelitian ini dimaksudkan untuk dapat mengungkap fenomena yang ada dan peneliti akan berupaya menemukan peristiwa-peristiwa yang dapat 
dipahami peneliti, berbagai pendapat dan isu yang ada, dan fenomena-fenomena yang nampak pada obyek penelitian, oleh karena itu dalam penelitian ini menggunakan pendekatan kualitatif dengan teori fenomenologi.

\section{Data, Sumber, Prosedur Pengumpula, analisis Data Penelitian}

Sumber data penelitian meliputi data primer (informan) dan data sekunder (bukan manusia). Sumber data primer yang dibutuhkan diantaranya kepala sekolah, guru,dan siswa. Adapun Prosedur pengumpulan data penelitian yang dilakukan dalam penilitian ini adalah dengan "wawancara, observasi, dan dokumentasi", sedangkan Analisis data penelitian yang digunakan adalah model Spradley (Etnografi) yaitu analisis data yang dikumpulkan dari observasi partisipan untuk menemukan pertanyaan. Menurut Spradley dalam Emzir (2010: 209) analisis data dengan model analisis Spradley mencakup empat kegiatan analisis yaitu: (1) analisis domain, (2) analisis taksonomi, (3) analisis komponen dan (4) analisis budaya.

\section{Pengecekan Keabsahan Temuan dan Tahap-Tahap Penelitian}

Pengecekan keabsahan temuan adalah bagian utama dalam penelitian kualitatif yaitu "untuk mengetahui dan mengecek kebenaran data yang diperoleh maka dilakukan pengecekan kredibilitas data dengan triangulasi”. Adapung Tahapan penelitian yang peneliti laksanakan atas empat tahap yaitu: Tahap pra lapangan, Tahap pekerjaan lapangan, Tahap analisis data, Tahap pelaporan.

\section{Pembahasan}

Dalam pembahasan ini, disajikan temuan-temuan di lapangan dan analisa secara komprehensif yang didasarkan pada teori-teori sebagai analisis atas fokus penelitian, Dalam pembahasan penelitian ini ada 4 fokus utama yang ditampilkan yaitu: (1) Kepala Sekolah membimbing guru Bahasa Indonesia dalam menyusun silabus mata pelajaran berdasarkan standar isi, standar kompetensi, dan kompetensi dasar serta prinsip-prinsip pengembangan Kurikulum Tingkat Satuan Pendidikan (KTSP) /Kurikulum tahun 2013 (K13), (2) Kepala Sekolah membimbing guru Bahasa Indonesia dalam memilih dan menggunakan strategi/metode/teknik pembelajaran, (3) Kepala Sekolah membimbing guru Bahasa Indonesia dalam menyusun rencana pelaksanaan pelajaran mata pelajaran Bahasa Indonesia, (4) Kepala Sekolah membimbing guru Bahasa Indonesia 
dalam mengelola, merawat, mengembangkan, dan menggunakan media atau Teknologi Informasi dan Komunikasi (TIK), (5) Implementasi supervisi akademik dalam meningkatkan kualitas pembelajaran di SMA dan SMK se-Kecamatan Abung Semuli, Lampung.

Analisis Data Pembahasan tentang kompetensi supervise akademik yang diterapkan oleh kepala sekolah dalam meningkatkan kualitas pembelajaran di SMA dan SMK se-Kecamatan Abun Semuli, Lampung adalah sebagai berikut:

Kepala sekolah membimbing guru bahasa indonesia dalam menyusun silabus mata pelajaran berdasarkan standar isi, standar kompetensi, dan kompetensi dasar serta prinsip-prinsip pengembangan $\mathbf{k t s p} / \mathbf{k 1 3}$

Langkah pengembangan silabus adalah sebagai berikut: (a). Pengembangan materi ajar yang dilakukan guru. Pada pelaksanaan supervisi akademik disusun pada awal tahun ajaran baru. Materi ajar berfungsi untuk membantu pelaksanaan belajar mengajar, dan dapat diajukan sebagai karya yang dinilai untuk menambah angka kredit Guru untuk keperluan kenaikan pangkat, selanjutnya akan menambah penghasilan Guru apabila karangannya diterbitkan, oleh karena itu, Guru Bahasa Indonesia harus menyiapkan terlebih dahulu materi ajar yang akan mereka sampaikan ketika pembelajaran. Guru tidak boleh hanya mengambil materi ajar dari satu sumber saja, Guru harus bisa mengembangkan materi ajar yang mereka akan sampaikan. Guru Bahasa Indonesia memiliki materi ajar yang telah disesuaikan dengan lingkungan tempat anak belajar jadi tidak melulu mengambil dari satu sumber dari buku saja, materi ajar juga telah disesuaikan dengan karakter anak dan lingkungan. (b) Pengembangan Standar Kompetensi. Pada setiap mata pelajaran, standar kompetensi sudah ditentukan oleh para pengembang kurikulum, yang dapat kita lihat dari standar isi. Jika sekolah memandang perlu mengembangkan mata pelajaran tertentu misalnya pengembangan kurikulum muatan local, maka perlu dirumuskan standar kompetensinya sesuai dengan nama mata pelajaran. Pengembangan Standar Kompetensi yang dilakukan di SMA dan SMK se-Kecamatan Abung Semuli, Lampung. SMA Negeri 1 Abung Semuli, Lampung dan SMK Muhammadiyah Abung Semuli, Lampung masih mengadakan pengembangan terhadap 
Standar isi yang telah dibuat oleh TIM pengembang disesuaikan dengan lingkungan, namun di SMK Bhakti Angkasa 3 Abung Semuli, Lampung mereka tidak mengembangkannya lagi hanya memakai yang sudah dikembangkan oleh TIM pengembang berdasarkan Standar Isi.(c). Pengembangan Kompetensi Dasar (KD) . Kompetensi Dasar adalah pengetahuan, keterampilan dan sikap minimal yang harus dicapai oleh siswa untuk menunjukkan bahwa siswa telah menguasai standar kompetensi yang telah ditetapkan, oleh karena itu maka kompetensi dasar merupakan penjabaran dari standar kompetensi. Kompetensi Dasar dikembangkan dengan memperhatikan karakteristik peserta didik, kemampuan awal, serta ciri-ciri dari suatu mata pelajaran. Dengan kata lain peserta didik diharapkan mampu menerapkan pengetahuan dan keterampilan yang dimilikinya sesuai dengan standar yang ditetapkan, maka guru Bahasa Indonesia di SMA dan SMK se-Kecamatan Abung Semuli, Lampung melakukan pengembangan Kompetensi Dasar (KD). (d) Pengembangan Indikator yang dilakukan Guru . Guru Bahasa Indonesia telah melakukan pengembagan Indikator. Indikator adalah penanda pencapaian KD yang ditandai dengan adanya perubahan perilaku yang dapat diukur yang mencakup sikap, pengetahuan, dan keterampilan. Indikator dikembangkan sesuai dengan karakteristik peserta didik, mata pelajaran, satuan pendidikan, potensi daerah dan dirumuskan dalam kata kerja operasional yang terukur dan dapat diobservasi. Pengembangan Indikator yang dilakukan oleh Guru Bahasa Indonesia.

\section{Kepala Sekolah membimbing guru Bahasa Indonesia dalam memilih dan menggunakan strategi/metode/teknik pembelajaran.}

Dalam menggunakan strategi/metode/teknik hal yang harus dibimbing oleh kepala sekolah adalah mengenai pengembangan metode penggunaan media pembelajaran dan menyajikan bahan ajar seperti berikut ini: (a) Pengembangan metode penggunaan media pembelajaran sebagai contoh dalam proses pembelajaran, hal yang harus diperhatikan ketika penyampaian materi / informasi berlangsung adalah keluasan, kedalaman dari materi pelajaran, selain itu juga waktu yang diperlukan untuk mengajarkan materi tersebut, dan kondisi yang tersedia di sekolah sehingga media menjadi efektif 
digunakan dalam proses pembelajaran. Kepala Sekolah harus ikut berperan dalam mengembangan metode penggunaan media pembelajaran yang dilakukan oleh guru Bahasa Indonesia dan Kepala Sekolah berperan aktif dalam pengembangan metode penggunaan media pembelajaran, (b) Penyajian bahan ajar yang dilakukan guru Bahasa Indonesia Dengan cara disusun dengan dibimbing oleh kepala sekolah, bahan ajar disusun secara sistematis agar memudahkan siswa dapat belajar secara mandiri dan dirancang sesuai kurikulum yang berlaku. Peran seorang guru dalam merancang ataupun menyusun bahan ajar sangatlah menentukan keberhasilan proses belajar dan pembelajaran karena Bahan ajar merupakan seperangkat sarana atau alat pembelajaran yang berisikan materi pembelajaran, metode, batasan-batasan, dan cara mengevaluasi yang didesain secara sistematis dan menarik dalam rangka mencapai tujuan yang diharapkan, yaitu mencapai kompetensi atau subkompetensi dengan segala kompleksitasnya.

Penyusun Rencana Pelaksanaan Pembelajaran (RPP) mata pelajaran Bahasa Indonesia dibuat oleh guru untuk membantunya dalam mengajar agar sesuai dengan Standar Kompetensi dan Kompetensi Dasar pada hari tersebut

RPP berisi pengaturan yang berkenaan dengan perkiraan atau proyeksi tentang apa yang akan dilakukan pada saat kegiatan belajar mengajar berlangsung, kemungkinan pelaksanaan pembelajaran sesuai dengan rencana pelaksanaan pembelajaran yang telah direncanakan ataupun tidak karena proses pembelajaran bersifat situasional, (a) Penulisan Indikator pencapaian kompetensi pada RPP mata pelajaran Bahasa Indonesia yang telah disusun secara benar yaitu dengan membuat Indikator sesuai cakupan sikap, pengetahuan, dan keterampilan. Indikator yang dikembangkan telah sesuai dengan karakteristik peserta didik, mata pelajaran, satuan pendidikan, potensi daerah dan dirumuskan dalam kata kerja operasional yang terukur dan/atau dapat diobservasi. Dengan adanya pengembangan indikator yang tepat dapat memudahkan guru Bahasa untuk mengembangkan materi pembelajaran, mendesain kegiatan pembelajaran, mengembangkan bahan ajar, dan merancang dan melaksanakan penilaian hasil belajar. Indikator merupakan penanda pencapaian Kompetensi Dasar yang ditandai oleh perubahan perilaku yang dapat 
diukur yang mencakup sikap, pengetahuan, dan keterampilan. Indikator dikembangkan sesuai dengan karakteristik peserta didik, mata pelajaran, satuan pendidikan, potensi daerah dan dirumuskan dalam kata kerja operasional yang terukur dan/atau dapat diobservasi. (b) Perumusan tujuan pembelajaran di dalam RPP mata pelajaran Bahasa Indonesia telah membuat tujuan pembelajaran. Tujuan pembelajaran yang baik adalah yang terukur dan operasional mengandung satu perilaku peserta didik yang akan diukur bukan dua atau lebih perilaku yang diukur. Terkadang masih ada rumusan tujuan pembelajaran yang mengandung lebih dari satu tingkah laku dari peserta didik yang akan diukur. untuk memudahkan perumusan tujuan yang diharapkan sebaiknya berpedoman pada rumus $\mathrm{ABCD}$ yaitu audience, behaviour, conditioning, degree. Dengan tujuan yang jelas dan operasional akan menjadikan guru maupun peserta didik memiliki kejelasan apa yang harus dicapai dan apa yang harus dilakukan untuk menyapainkan materi yang seperti apa yang akan disiapkan seorang guru serta bagaimana menyampaikannya akan tergambar jelas dalam tujuan yang spesifik tersebut. (c) Penentukan alokasi waktu di setiap RPP mata pelajaran Bahasa Indonesia ditentukan sesuai dengan kebutuhan kebutuhan materi ajar yang tertera pada silabus pembelajaran. Menghitung Alokasi Waktu menjadi salah satu tahap awal dalam penyusunan Perangkat Pembelajaran oleh Guru. Dengan dasar Kalender Pendidikan kita akan mengetahui berapa Alokasi Waktu yang tersedia untuk kita dalam mengaplikasikan Kompetensi Inti (KI) dan Kompetensi Dasar (KD) yang diberikan pemerintah melalui kegiatan belajar mengajar yang kita laksanakan, jika kita melihat Silabus, Prota dan Prosem, semuanya mengandung Alokasi Waktu pada setiap KI dan KD yang kita jabarkan. Jadi dengan kata lain, Sebelum menyusun Silabus, Prota, Promes dan RPP, kita harus menentukan Alokasi Waktu tersebih dahulu berdasarkan Kalender Pendidikan Tahun Pelajaran yang akan dijalani. (d) Perumusan kegiatan pembelajaran pada RPP mata pelajaran Bahasa Indonesia merupakan implementasi dari RPP, meliputi kegiatan pendahuluan, inti dan penutup. Dalam pelaksanaan pembelajaran di kelas, guru wajib untuk menerapkan pembelajaran yang awali dengan kegiatan pendahuluan, inti dan kegiatan penutup, hal ini dilakukan agar proses pembelajaran berjalan baik dan sesuai dengan rencana pembelajaran. Seperti yang telah dilaksanakan oleh 
guru Bahasa Indonesia melaksanakan kegiatan pembelajaran dalam tiga langkah yaitu kegiatan pendahuluan, kegiatan inti, dan kegiatan penutup. Kegiatan pendahuluan mencakup menyiapkan peserta didik mengikuti proses pembelajaran, memberi motivasi belajar peserta didik Mengajukan pertanyaan-pertanyaan yang mengaitkan pengetahuan sebelumnya dengan materi yang akan dipelajari, menjelaskan tujuan pembelajaran atau kompetensi dasar yang akan dicapai, serta menyampaikan cakupan materi dan penjelasan uraian kegiatan sesuai silabus. Kegiatan inti menggunakan model pembelajaran, metode pembelajaran, media pembelajaran, dan sumber belajar yang disesuaikan dengan karakteristik peserta didik dan mata pelajaran, sedangkan dalam kegiatan penutup, guru bersama peserta didik baik secara individual maupun kelompok melakukan refleksi pembelajaran pada hari itu.

\section{Kepala Sekolah membimbing guru Bahasa Indonesia dalam mengelola, merawat, mengembangkan, dan menggunakan media/TIK}

seperti Ms.Word, Ms Exel, dan power point dapat memudahkan guru menyiapkan media pembelajaran maupun perangkat pembelajaran seperti RPP, bahan/materi ajar, lembar kerja siswa, maupun soal evaluasi, serta memudahkan para guru dalam meningkatkan kualitas pembelajaran di kelas, oleh karena itu guru dituntut untuk dapat menggunakan TIK, agar guru dapat mengelola, merawat, mengembangkan, dan menggunakan media/TIK dengan baik diperlukanlah bimbingan dari Kepala Sekolah selaku pemimpin. Berdasarkan penelitian di SMA dan SMK se-Kecamatan Abung Semuli, Lampung diperoleh temuan data sebagai berikut: (a) Kepala Sekolah membimbing guru Bahasa Indonesia dalam mengelola dalammeningkatkan pengajaran dan pembelajaran yang dinamis, interaktif, fleksibel, dan konten menarik. TIK memberikan kesempatan nyata untuk instruksi individual. Selain itu, informasi dan teknologi komunikasi memiliki potensi untuk mempercepat, memperkaya, dan memperdalam keterampilan, untuk memotivasi dan melibatkan para siswa dalam belajar, untuk membantu menceritakan pengalaman sekolah untuk praktek kerja, untuk membantu menciptakan kelayakan ekonomi bagi pekerja besok, memberikan kontribusi untuk perubahan di sekolah; untuk memperkuat mengajar, 
dan untuk memberikan kesempatan bagi hubungan antara sekolah dan dunia, oleh karena itu, Kepala Sekolah perlu membimbing guru Bahasa Indonesia dalam mengelola TIK karena TIK saat ini sangat erat dengan dunia pendidikan. (b) Kepala Sekolah membimbing guru Bahasa Indonesia dalam merawat TIK. Pembelajaran Teknologi Informasi dan Komunikasi akan memberikan motivasi dan kesenangan kepada siswa supaya siswa lebih mudah belajar dan bekerja secara mandiri. Dengan demikian, sangat penting Kepala Sekolah membimbing guru Bahasa Indonesia dalam merawat TIK. Untuk merawat alat TIK Kepala Sekolah menyediakan ruangan khusus dan lemari-lemari khusus sebagai tempat penyimpanan, kemudian menunjuk salah satu guru sebagai penanggung jawab membantu guru untuk merawat alat TIK. Alat-alat TIK di sekolah perlu dirawat agar dapat digunakan dalam jangka panjang, kepala sekolah, guru, dan siswa harus bekerja sama dalam merawat alat TIK tersebut. Karena, pada saat ini alat TIK benar-benar menjadi bagian dari pembelajaran, untuk menciptakan pembelajaran yang inovatif dan menarik. (c) Kepala Sekolah membimbing guru Bahasa Indonesia agar kemampuannya meningkat dalam menggunakan media TIK yang sangat berperan dalam dunia pendidikan salah satunya adalah dapat membuat perpustakaan online (Digital Library), buku sekolah elektronik (e-book), ataupun kelas online (e-learning). Maka sangat diperlukan sekali bimbingan Kepala Sekolah agar guru Bahasa Indonesia dapat meningkatkan kemampuannya dalam menggunakan media TIK. Kepala Sekolah telah mengadakan pelatihan TIK sebagai upaya meningkatkan kemampuan guru dalam menggunakan media TIK. Selain itu Kepala Sekolah selalu membimbing guru untuk saling membantu jika mengalami kesulitan dalam menggunakan Media TIK.

\section{Implementasi supervisi akademik dalam meningkatkan kualitas pembelajaran.}

Pelaksanakan supervisi akademik merupakan bentuk penilaian dalam meningkatkan kualitas pembelajaran yang dituangkan dalam bentuk lembaran-lembaran instrumen supervisi akademik. Instrumen supervisi akademik yang berupa lembaran-lembaran berisi berbagai pertanyaan yang terkait dengan administrasi pembelajaran tersebut kemudian diisi dengan cara mencentang pada kolom yang sudah 
ditentukan. Selain berisi berbagai pertanyaan yang diisikan pada kolom tersendiri. Setelah supervisor selesai mengisi dan menuliskan temuan- temuan tersebut kemudian hasilnya di jumlah agar diketahui berapa persen tingkat keberhasilan yang dilakukan.Dalam hal ini supervisi akademik terhadap guru dibuktikan dengan adanya lembar observasi supervisi akademik. Program Supervisi Akademik yang dilakukan adalah sebagai berikut: Pembinaan 1 bulan sekali oleh pengawas mata pelajaran, Pembinaan kedalam kelas 1 tahun sekali, Supervisi tidak terjadwal/insendental, Supervisi kelompok (rapat rumpun per mata pelajaran), Evaluasi diri setiap akhir semester, Mengirim guru untuk mengikuti program pelatihan, Studi lanjut atau penyesuaian.

Memperhatikan temuan pelasanaan kunjungan kelas dapat dikemukakan bahwa kunjungan kelas atau supervisi kelas dilakukan minimal 1 tahun sekali, dengan kepala sekolah sebagai supervisor atau dibantu oleh guru-guru senior yang dipercaya oleh kepala sekolah untuk menjadi supervisor karena mengingat banyaknya dewan guru yang harus disupervisi. Selain supervisi yang terjadwal adapula supervisi yang tidak terjadwal, hal ini dilakukan karena kepala sekolah menginginkan setiap guru bisa selalu berinovatif dalam pembelajaran tidak hanya dipersiapkan ketika adanya jadwal supervisi saja, agar setiap siswa dapat mendapatkan pembelajaran yang berkualitas setiap harinya.

Setelah dilaksanakan supervisi memang terlihat jelas perbedaan kualitas hasil pembelajaran bagi "guru yang disupervisi oleh kepala sekolah" dengan guru yang tidak disupervisi oleh kepala sekolah, berdasarkan temuan yang didapatkan dalam proses penelitian ddapatkan guru yang disupervisi akan lebih tertib dalam administrasi pembelajaran, lebih disiplin, dan lebih bervariatif dalam menggunakan metode pembelajaran, sehingga akan lebih meningkatkan minat siswa dalam belajar.

Guru yang tidak pernah mengalami supervisi biasanya akan lebih santai dalam menyiapkkan administrasi pembelajaran, mereka akan mulai menyiapkan administrasi apabila akan ada pengawas atau pada saat akan diadakannya proses akreditasi. Ditemukan guruguru yang bahkan masih kebingungan dalam menyiapkan perangkat pembelajaran yang benar walaupun sudah bertahun-tahun menjadi guru. Kurang variatifnya metode pembelajaran yang digunakan, 
masih menggunakan metode mencatat, sehingga kurang menari kminat siswa dalam belajar.

Argumen yang sama mengenai supervisi (Arikarani 2016, 101) merupakan suatu upaya yang sistematik peran dan pencapaian keberhasilannya oleh supervisor selaku satu elemen tenaga kependidikan salah satu elemen tenaga kependidikan yang menjadi ujung tombak demi terciptanya mutu pendidikan yang mumpuni. Supervisor bertugas melaksanakan pengawasan akademik dan manajerial sekolah ditunjuk melalui pemantauan, penilaian, dan pembinaan serta laporan dan tindak lanjut. Semuanya akan terwujud jika sebuah satuan pendidikan berada dibawah pembinaan seorang supervisor yang baik dalam hal ini adalah Kepala sekolah.

Implementasi Supervisi Akademik dalam Meningkatkan Kualitas Pembelajaran maka Kepala sekolah menggunakan cara tersendiri dalam melakukan supervisi akademik dengan tetap memperhatikan standar proses sesuai standar penilaian, sedangkan pada guru Bahasa Indonesia lebih ditekankan pada materi pelajaran Bahasa Indonesianya sehingga berbeda dengan mata pelajaran umum. Kepala sekolah masuk sendiri ke dalam kelas dan melakukan mikro teaching minimal satu jam mata pelajaran terhadap guru yang ditunjuk, sehingga ketika nantinya mendelegasikan terhadap guru untuk melakukan supervisi kelas dan ditemui temuan-temuan maka kepala sekolah tidak lagi menyalahi prosedur supervisi dikarenakan juga ditemui perbedaan di dalam kelas dalam melakukan pembelajaran karena guru Bahasa Indonesia memiliki pemahaman yang berbeda, hal ini dibuktikan dengan hasil pelaksanaan penilaian guru Bahasa Indonesia di kelas berupa lembar supervisi yang berbeda-beda dalam hasil supervisinya. Sebelum dilaksanakan proses pelaksanaan supervisi akademik oleh kepala sekolah dilakukan sosialisasi semua program kepala sekolah terlebih dahulu terhadap semua warga sekolah secara berkala termasuk program supervisi terhadap guru Bahasa Indonesia dengan maksud agar guru Bahasa Indonesia melakukan persiapan dan mengetahui bahwa suatu saat akan dilakukan pemantauan sehingga dari pihak sekolah bisa mengetahui apa yang dibutuhkan guru-guru agar pembelajaran dapat berjalan sebagimana mestinya.

\section{Simpulan}


Berdasarkan dari pembahasan tentang Kepala Sekolah di SMA dan SMK se-Kecamatan Abung Semuli, Lampung, Indonesia didapatkan simpulan sebagai berikut : Telah memberikan bimbingan kepada guru Bahasa Indonesia dalam menyusun silabus mata pelajaran berdasarkan standar isi, standar kompetensi, dan kompetensi dasar serta prinsip-prinsip pengembangan KTSP/K13. Telah membimbing guru Bahasa Indonesia dalam memilih dan menggunakan strategi/metode/teknik pembelajaran. Telah membimbing guru Bahasa Indonesia dalam menyusun Rencana Pelaksanaan Pembelajaran (RPP) mata pelajaran Bahasa Indonesia. Telah membimbing guru Bahasa Indonesia dalam mengelola, merawat, mengembangkan, dan menggunakan media. Telah mengimplementasi supervisi akademik terhadap guru Bahasa Indonesia, dibuktikan dengan adanya pembinaan 1 bulan sekali oleh pengawas mata pelajaran, pembinaan kedalam kelas 1 tahun sekali, supervisi tidak terjadwal/insendental, Supervisi kelompok (rapat rumpun per mata pelajaran), evaluasi diri setiap akhir semester dan mengirim guru untuk mengikuti program pelatihan, studi lanjut atau penyesuaian untuk meningkatkan kualitas pembelajaran. 
192 Nining, M. Ihsan, Sudirman, Implementasi Supervisi....

\section{DAFTAR PUSTAKA}

Arikarani, Yesi. 2016. "Analisis Kompetensi Supervisor Dalam Bidang PAI Di SMA Negeri 17 Kota Palembang." el-Ghiroh XI(02 September): 99-117.

Arikunto, Suharsimi. 2010. Prosedur Penelitian (Suatu Pendekatan Praktek). Jakarta. Rineka Cipta.

Arikunto, Suharsimi. 2006. Prosedur Penelitian. Jakarta. Bina Aksara.

Astuti , Rubiyah dan Dacholfany M. Ihsan, 2016 , Pengaruh Supervisi Pengawas Sekolah Dan Kepemimpinan Kepala Sekolah Terhadap Kinerja Guru Smp Di Kota Metro Lampung, Jurnal Lentera LPPM, Universitas Muhammadiyah Metro, Vol.1 No.2 Desember .

Budiono, 1994. Manajemen Pembelajaran. Jakarta: Erekha Cipta. Direktorat Tenaga Kependidikan, 2009, Jakarta.

Mukhtar dan Iskandar. 2013. Orentasi Baru Supervisi Pendidikan. Jakarta.Gaung Persada Press Group.

Nining Surya Ningsih, M. Ihsan Dacholfany, Sudirman Aminin'2018, Implementasi Supervisi Akademik Dalam Meningkatkan Kualitas Pembelajaran Di SMA Dan Smk Se-Kecamatan Abung Semuli Lampung Indonesia, Jurnal Lentera Pendidikan 
Pusat Penelitian LPPM UM METRO Vol. 3. No. 2, Desember 2018

Sallis, E. 2007. Total Quality Management in Education. Alih Bahasa: Ahmad Ali Riyadi dan Fahrorrozi. Yogyakarta: IRCISoD

Sinta Oktavianti , M. Ihsan Dacholfany, Agus Sutanto, 2019, Pengaruh Kepemimpinan Kepala Sekolah Dan Perilaku Kewarganegaraan Organisasi Terhadap Kinerja Guru Di Smp Se-Kecamatan Purbolinggo Kabupaten Lampung Timur, Jurnal Lentera Pendidikan Pusat Penelitian LPPM UM METRO Vol. 4. No. 2 Desember 2019.

Sugiyono, 2009.Metode Penelitian kuantitatif, Kualitatif dan $R \& D$. Bandung.Alfabeta.

Suhardan, Dadang. 2010: 55). Program Layanan Supervisi Peningkatan Mutu.Jakarta.BalaiPustaka

Sudjana, Nana. 2005. Penilaian Hasil Proses Belajar Mengajar. Bandung: Remaja Rosdakarya.

Sudjana, Nana. 2010. Kompetensi Pengawas Sekolah Dimensi dan Indikator. Jakarta. Binamitra

Yunia Sari Reziki, M. Ihsan Dacholfany, 2018, Pengaruh Supervisi Akademik Kepala Sekolah Dan Kompetensi Pedagogik Terhadap Mutu Sekolah Di Sma Se-Kecamatan Pekalongan Lampung Timur, Jurnal Lentera Pendidikan Pusat Penelitian LPPM UM Metro Vol. 3. No. 2, Desember 2018.

Universitas Muhammadiyah Metro. 2015. Pedoman Penulisan Karya Ilmiah(PPKI). Metro. Universitas Muhammadiyah Metro. 